\title{
Analisis dan Pengukuran Rangkaian Pengisi Baterai pada Beberapa Produk Lampu Baca
}

\author{
Fransiscus Dalu Setiaji \\ Program Studi Teknik Elektro, \\ Fakultas Teknik Elektronika dan Komputer, \\ Universitas Kristen Satya Wacana, Salatiga \\ dalu.setiaji@uksw.edu
}

\begin{abstract}
Ringkasan
Produk lampu baca yang dilengkapi baterai isi ulang banyak yang beredar tanpa tanda SNI, seperti empat macam produk lampu yang diteliti pada makalah ini. Penelitian difokuskan pada bagian utamanya yaitu charger baterai, untuk mengetahui metode pengisian baterai SLA yang digunakan. Rangkaian charger akan dianalisis dan diverifikasi melalui simulasi maupun pengukuran. Kondisi pengujian yang dipilih adalah dengan terus menghubungkan produk lampu dengan jala-jala PLN, dalam rentang waktu lama yaitu tiga bulan, sehingga metode pengisian baterai yang cocok adalah float charging. Namun arus pengisian rerata yang digunakan pada semua produk terlalu besar, antara $C_{\text {bat }} / 28$ sampai $C_{\text {bat }} / 14$, melebihi yang disarankan yaitu $C_{\text {bat }} / 500$, sehingga terjadi overcharging. Akibatnya empat baterai dengan arus pengisian terbesar mengalami kerusakan yaitu satu baterai dengan arus $C_{b a t} / 17$ dan tiga baterai yang dengan arus $C_{\text {bat }} / 14$. Ketiga baterai dengan arus rerata $C_{\text {bat }} / 14$ tersebut juga memiliki riak arus pengisian yang melebihi ketentuan yaitu $C_{\text {bat }} / 20$. Analisis dan pengukuran selanjutnya menunjukkan kerusakan baterai akan berimbas pada rusaknya kapasitor perata arus karena mendapatkan tegangan $62 \mathrm{~V}$ sampai $95 \mathrm{~V}$ sedangkan rating-nya hanya $16 \mathrm{~V}$ sampai $50 \mathrm{~V}$. Kerusakan baterai juga mengakibatkan kerusakan resistor pada rangkaian indikator LED, pada salah satu jenis produk lampu, karena resistor yang rating dayanya hanya $0,25 \mathrm{~W}$ mendapatkan daya rerata $0,49 \mathrm{~W}$ dan daya puncak $9,8 \mathrm{~W}$.
\end{abstract}

Kata kunci: produk, lampu baca, baterai, charger, overcharging

\section{Pendahuluan}

\subsection{Latar Belakang}

Ketersediaan cahaya penerangan di dalam rumah terutama pada saat malam hari sangat dibutuhkan oleh warga masyarakat, antara lain untuk keperluan membaca dan belajar. Pada umumnya cahaya penerangan berasal dari lampu yang dicatu oleh sumber listrik PLN (Perusahaan Listrik Negara). Masalah akan muncul jika listrik padam terkecuali jika terdapat sumber energi alternatif untuk tetap dapat menyalakan lampu.

Salah cara mengatasinya adalah dengan menggunakan produk lampu baca yang di dalamnya telah terdapat baterai yang dapat diisi ulang. Wujud fisik lampu tersebut beraneka ragam, di antaranya berbentuk lampu duduk yang mudah diletakkan di meja belajar. Baterai diisi ulang pada saat listrik PLN tersedia, jika listrik padam maka baterai dapat mencatu lampu baca selama selang waktu tertentu. 
Lampu baca semacam itu mudah diperoleh di toko listrik maupun di berbagai situs jual beli online. Banyak produk lampu baca yang belum bertanda SNI (Standar Nasional Indonesia). Padahal ada standar wajib SNI IEC 60335-1:2009 yang ruang lingkupnya mencakup keselamatan peranti listrik untuk keperluan rumah tangga bertegangan di bawah $250 \mathrm{~V}$, seperti tegangan yang dipakai produk lampu baca tersebut.

Berdasarkan uraian di atas, maka dalam makalah ini dilakukan penelitian pada empat jenis produk lampu baca yang dilengkapi baterai isi ulang, yang semuanya belum bertanda SNI. Penelitian difokuskan pada bagian pengisi baterai (charger) yang bisa menimbulkan potensi kerusakan jika tidak dirancang atau digunakan dengan benar.

Kondisi pengujian yang dipilih adalah lampu terus dihubungkan dengan sumber listrik PLN. Alasan pemilihan kondisi ini adalah karena pada umumnya pengguna menginginkan baterai terisi penuh setiap saat. Selain itu adanya anggapan bahwa daya yang diserap charger kecil sehingga banyak pengguna membiarkan charger elektronik terus terhubung ke sumber listrik PLN [1].

\subsection{Tinjauan Pustaka}

\subsubsection{Baterai Asam-Timbal (Lead-Acid Battery)}

Baterai asam-timbal merupakan baterai sekunder, yang energinya bisa diisi ulang. Baterai ini memiliki keunggulan yaitu proses pengisian baterai (perubahan energi listrik ke kimia) dan pengosongannya (perubahan energi kimia ke listrik) dapat dilakukan bergantian secara efisien, tanpa banyak mempengaruhi kapasitas baterai. Sekalipun kepadatan energinya relatif rendah namun baterai ini mampu beroperasi pada rentang suhu yang lebar dan harganya murah. Kapasitas baterai asam-timbal tersedia mulai dari beberapa ratus mAh sampai diatas 10.000Ah. Kapasitas baterai, Cbat, dinyatakan dalam Ah, menunjukkan nilai arus yang bisa dialirkan selama satu jam sampai baterai kehabisan energi. Sedangkan tegangan nominal atau tegangan operasional baterai ini adalah $2 \mathrm{~V}$ untuk tiap sel baterai.

Salah satu teknologi paling populer dalam produksi baterai asam-timbal adalah VRLA (Valve Regulated Lead-Acid) atau SLA (Sealed Lead-Acid). Teknologi ini dapat mereduksi jumlah gas oksigen $\left(\mathrm{O}_{2}\right)$ maupun hidrogen $\left(\mathrm{H}_{2}\right)$ yang dilepaskan selama proses pengisian, dibandingkan dengan baterai asam-timbal basah (flooded), sehingga mengurangi bahaya terjadinya ledakan maupun penurunan kapasitas baterai.

\subsubsection{Metode Pengisian Baterai SLA}

Ada beberapa metode standar pengisian baterai SLA yaitu Tegangan Konstan, Pengisian Float dan Arus Konstan.

\section{Pengisian dengan Tegangan Konstan (Constant Voltage Charging)}

Metode ini, yang biasa disingkat $\mathrm{CV}$, memungkinkan baterai SLA diisi secara efisien dan cepat. Efisiensi Arus-Pengisian adalah perbandingan nilai arus yang dipergunakan untuk proses konversi energi elektro-kimia terhadap nilai arus pengisian baterai. Grafik tegangan pengisian terhadap nilai efisiensi arus-pengisian untuk metode CV ditunjukkan Gambar 1, yang mengindikasikan bahwa nilai efisiensi akan mendekati $100 \%$ pada rentang tegangan $2,2 \mathrm{~V}$ sampai $2,4 \mathrm{~V}$. 


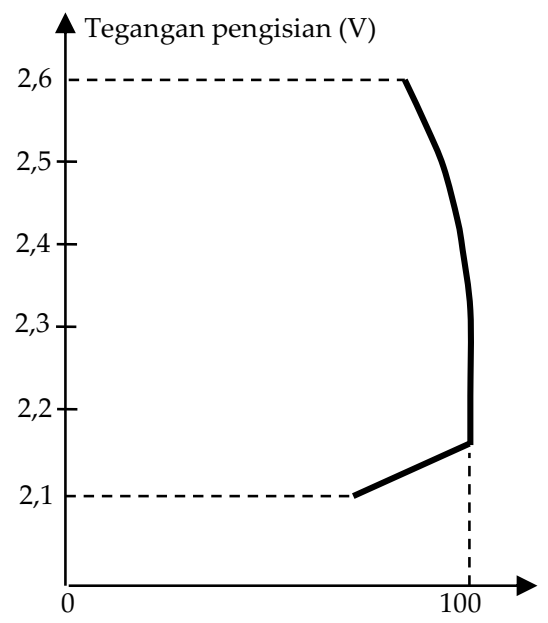

Efisiensi Arus Pengisian (\%)

Gambar 1. Grafik tegangan pengisian terhadap nilai efisiensi arus-pengisian pada metode CV [2]

\section{Pengisian Float (Float Charging)}

Jika baterai SLA diaplikasikan sebagai baterai cadangan (back-up) dalam suatu sistem, maka baterai tersebut diisi dengan cara float charging. Agar baterai berumur panjang, tegangan baterai harus berada di antara 2,3 sampai 2,4V[2]. Pengisian dengan tegangan di atas 2,4V menyebabkan terjadinya korosi pada grid baterai. Gambar 2 menunjukkan perkiraan tegangan baterai saat mengalami float charging pada suhu $25^{\circ} \mathrm{C}$ dan $65^{\circ} \mathrm{C}$. Arus Cbat pada gambar adalah besarnya arus pengisian dalam A, yang nilainya sama dengan besarnya Cbat dalam Ah.

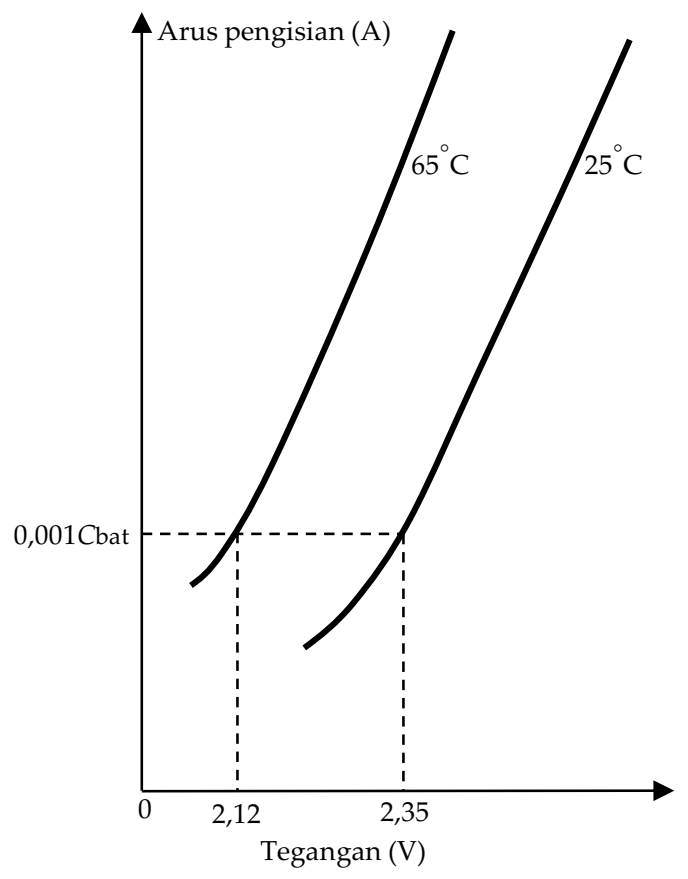

Gambar 2. Grafik nilai arus pengisian terhadap tegangan baterai dengan metode float charging [2] 
Gambar 2 menunjukkan bahwa pada suhu $25^{\circ} \mathrm{C}$, baterai yang yang sudah penuh namun diisi terus dengan arus kecil (trickle current) 0,001C maka bertegangan 2,35V. Namun pada suhu $65^{\circ} \mathrm{C}$, dengan arus yang sama, tegangannya hanya $2,12 \mathrm{~V}$ yang berarti tidak memenuhi persyaratan.

\section{Pengisian dengan Arus Konstan (Constant Current Charging)}

Pengisian dengan metode ini, yang biasa disingkat $\mathrm{CI}$, juga termasuk pengisian baterai SLA yang efisien. Grafik efisiensi arus-pengisian terhadap arus pengisian ditunjukkan Gambar 3.

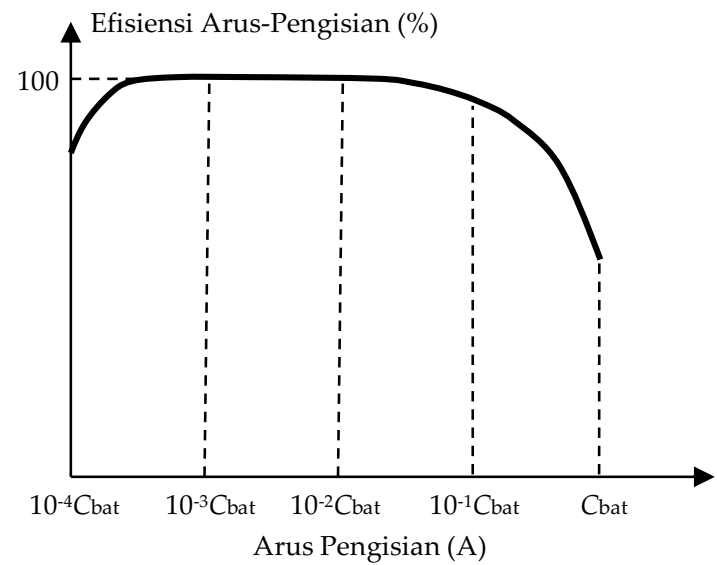

Gambar 3. Grafik efisiensi arus-pengisian terhadap nilai arus pengisian pada metode CI [2]

Gambar 3 menunjukkan arus pengisian sebesar $\mathrm{Cbat}_{\mathrm{bat}} / 1000$ sampai $\mathrm{C}_{\text {bat }} / 100$ menghasilkan efisiensi mendekati $100 \%$. Jika arus pengisian diperbesar maka efisiensi menurun karena pada saat sel sudah penuh, energi listrik yang diterima baterai tidak dapat disimpan lagi, melainkan digunakan untuk menghasilkan gas $\mathrm{O}_{2}$ dan $\mathrm{H}_{2}$ yang akhirnya harus dibuang baterai. Pada nilai arus pengisian yang rendah, efisiensi juga menurun karena nilai arus tersebut setara dengan arus bocor (parasitic) baterai sehingga tegangan baterai akan mendekati nilai hubung bukanya.

Tiga metode standar di atas memiliki kelemahan masing-masing. Metode CI beresiko menghasilkan gas berlebih ketika baterai penuh, sedangkan CV mengakibatkan terjadinya arus yang besar pada saat awal pengisian baterai. Sedangkan float charging dapat menimbulkan pengisian berlebihan (overcharging).

Untuk itu dikembangkan metode yang menggabungkan keduanya (metode CICV), $\mathrm{CI}$ digunakan pada awal pengisian dan $\mathrm{CV}$ digunakan pada saat baterai mendekati penuh. Untuk melaksanakan metode tersebut dibutuhkan catu daya yang 'cerdas', seperti yang digunakan pada [3], yang memungkinkan pengguna memasukkan data rentang kapasitas baterai yang akan diisi. Hasil pengukuran menunjukkan pada saat awal pengisian baterai diisi dengan arus konstan untuk waktu yang lama, setelah baterai penuh maka tegangan pengisian secara otomatis menjadi konstan dan arus pengisian mengecil menjadi sekitar $\mathrm{Cbat}_{\mathrm{bat}} / 90$. Metode $\mathrm{CICV}$ mempunyai kelemahan yaitu setelah baterai penuh, baterai terus diisi sehingga mengalami overcharged, walaupun dengan arus yang relatif kecil dibanding menggunakan metode CI saja.

Metode selanjutnya adalah $\mathrm{CICVCV}$, yaitu pengisian dengan $\mathrm{CI}$, diikuti $\mathrm{CV}$ dengan tegangan relatif tinggi dan diakhiri dengan $\mathrm{CV}$ menggunakan tegangan lebih rendah. Peralihan antar CV tersebut dilakukan dengan syarat tertentu, misalnya jika CV yang 
pertama telah dilaksanakan selama delapan jam. Metode ini tetap membuat baterai mengalami overcharged meskipun tidak sebesar pada CICV.

Metode yang lebih baru untuk menghindari masalah tersebut adalah IC (Intermittent Charge) yang mempunyai dua mode pengisian yaitu CI dan IC. Pada saat awal pengisian digunakan mode $\mathrm{CI}$, yaitu pengisian menggunakan arus konstan. Setelah tegangan baterai mencapai batas atas tertentu maka mode beralih ke IC. Pada mode IC baterai diisi dengan arus kecil konstan dengan durasi pendek, lalu dibiarkan terbuka (open circuit) sampai tegangannya meluruh ke batas bawah tertentu yang memicu pengisian dengan arus kecil konstan lagi. Mode IC ini akan mengurangi tingkat overcharging dibandingkan CICVCV. Pengembangan selanjutnya adalah metode ICC (Intermittent Charge Control) seperti pada [4] yang ditujukan untuk mencegah terjadinya undercharging pada mode IC. Terdapat pula metode seperti pada [5] yang menggunakan lima tahap pengisian baterai untuk mengatasi masalah yang muncul pada awal pengisian (adanya arus besar) dan pada akhir pengisian, yaitu adanya stratifikasi atau penumpukan asam timbal di dasar baterai, akibat float charging.

Setelah baterai diisi dan dikosongkan berulangkali, terdapat mekanisme yang akan memperpendek umur baterai yang disebut sulfasi, yang merupakan efek lanjutan dari stratifikasi. Sulfasi mengakibatkan baterai kehilangan material aktif untuk reaksi elektrokimia sehingga kapasitasnya menurun. Maka dibutuhkan proses desulfasi untuk mengembalikan sebagian kapasitasnya, salah satunya dengan metode Pressure Feedback Control Charging [6]. Terdapat banyak metode sulfasi, hasil komparasinya seperti pada [7] mengarah pada kesimpulan bahwa metode sulfasi selanjutnya sebaiknya memanfaatkan AI (Artificial Intelligent).

Pengisian baterai merupakan proses yang gayut waktu (time dependent) dan nonlinear sehingga sulit dipenuhi menggunakan teknik kendali standar. Oleh sebab itu strategi pengisian baterai juga dikembangkan menggunakan kendali samar (fuzzy control) seperti pada [8] dengan hasil yang memuaskan, meskipun belum memasukkan unsur suhu sebagai masukan sistem kendali.

Permasalahan utama pengisian baterai adalah menentukan nilai State Of Charge (SOC)

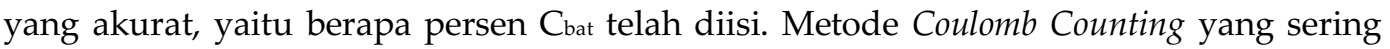
digunakan untuk memprediksi nilai SOC ternyata memiliki ralat besar karena menghasilkan pengukuran kapasitas baterai yang terlalu rendah dibanding nilai sesungguhnya. Salah satu perbaikan adalah dengan memodifikasi metode tersebut diunjukkan pada [9]. Sedangkan untuk sistem baterai yang lebih kompleks, maka diperlukan pemodelan yang lebih tepat, seperti pada [10] yang berhasil menerapkan algoritma Particle Swamp Optimization and Perturbation untuk memodelkan SOC battery bank yang terdiri dari 24 baterai.

Berdasarkan tinjauan pustaka-pustaka di atas maka akan diteliti metode pengisian mana yang dipakai oleh charger pada produk lampu, yang semuanya menggunakan baterai SLA.

\section{Pelaksanaan Penelitian}

\subsection{Produk Lampu yang Diteliti}

Ada empat macam produk lampu baca pada penelitian ini seperti ditunjukkan pada Gambar 4. Merk dan tipe lampu diganti dengan sebutan Lampu- $A,-B,-C$ dan $-D$ seperti yang tertera pada gambar tersebut. Keempat lampu tersebut dipilih karena rangkaian 
charger-nya serupa. Jumlah produk lampu yang diteliti untuk masing-masing jenis adalah tiga buah.

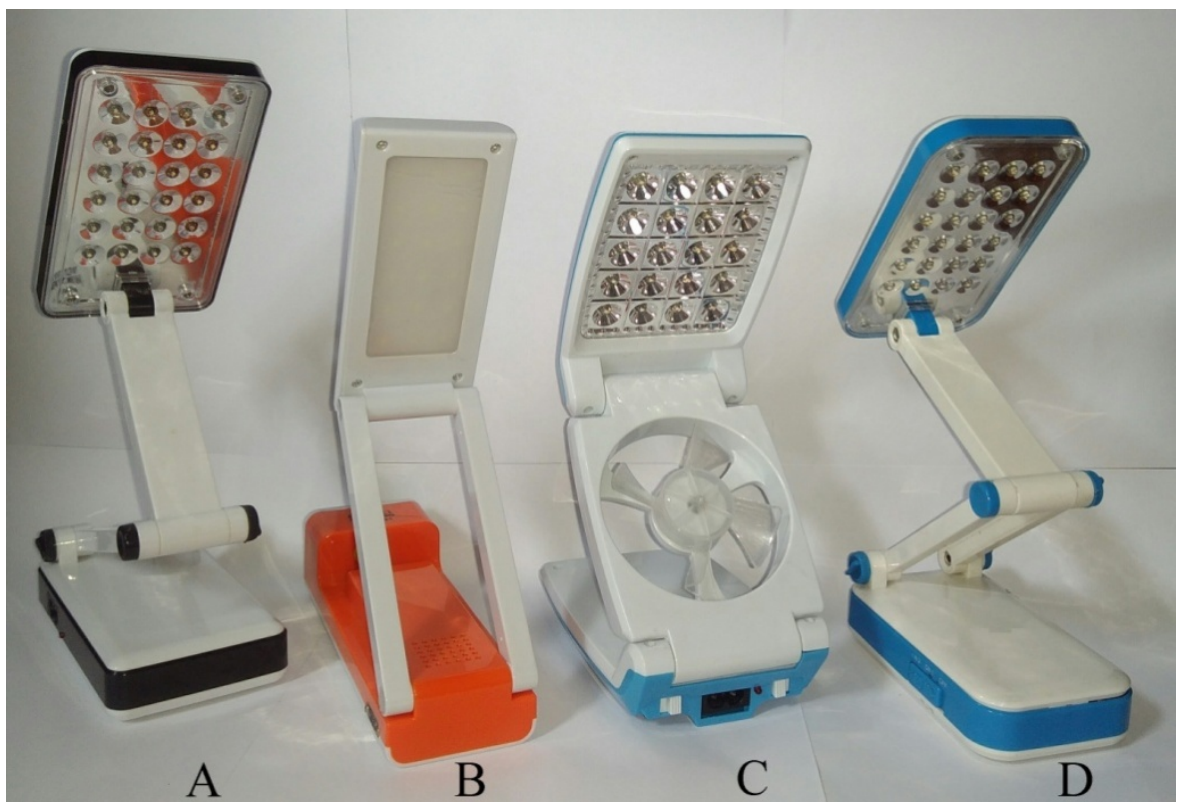

Gambar 4. Gambar jenis produk lampu baca yang diteliti

Langkah pertama yang dilakukan adalah menggambar ulang rangkaian elektronik di dalamnya, dengan hasil seperti ditunjukkan Gambar 5 sampai Gambar 8.

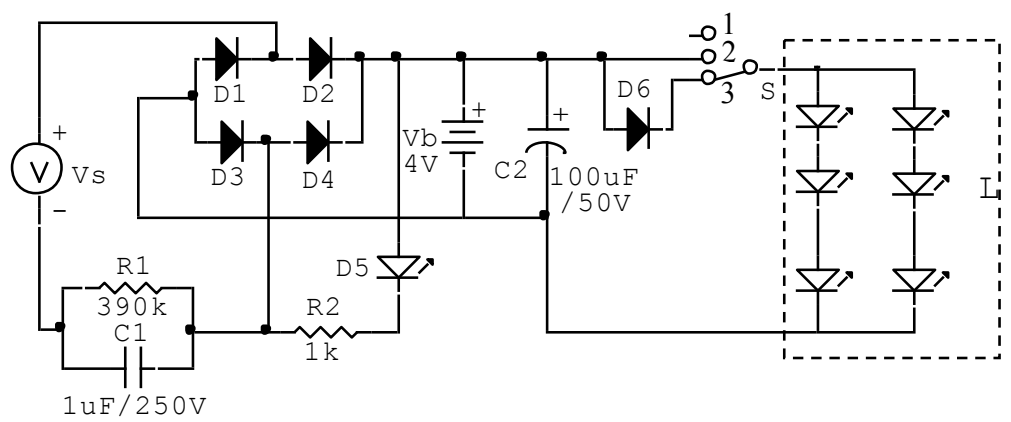

Gambar 5. Diagram rangkaian Lampu- $A$

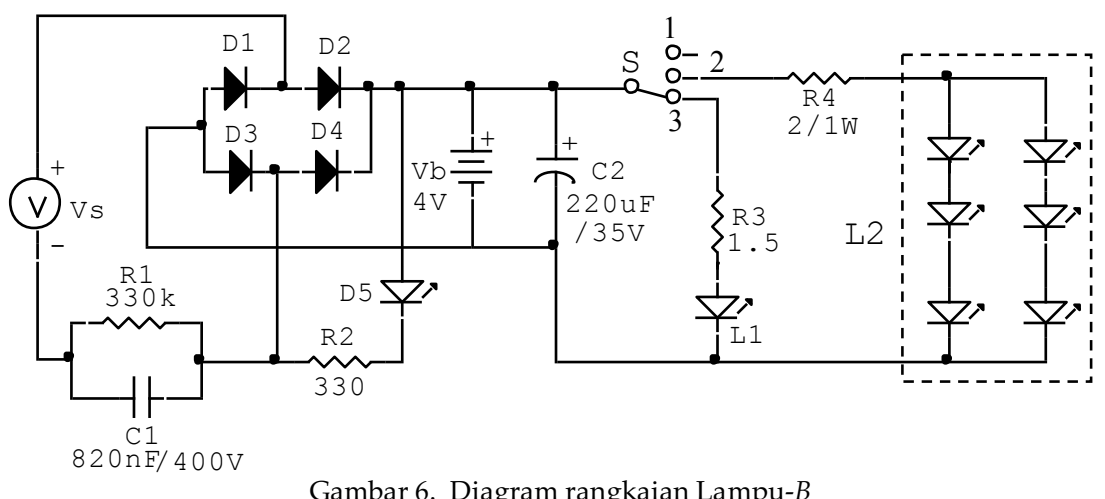




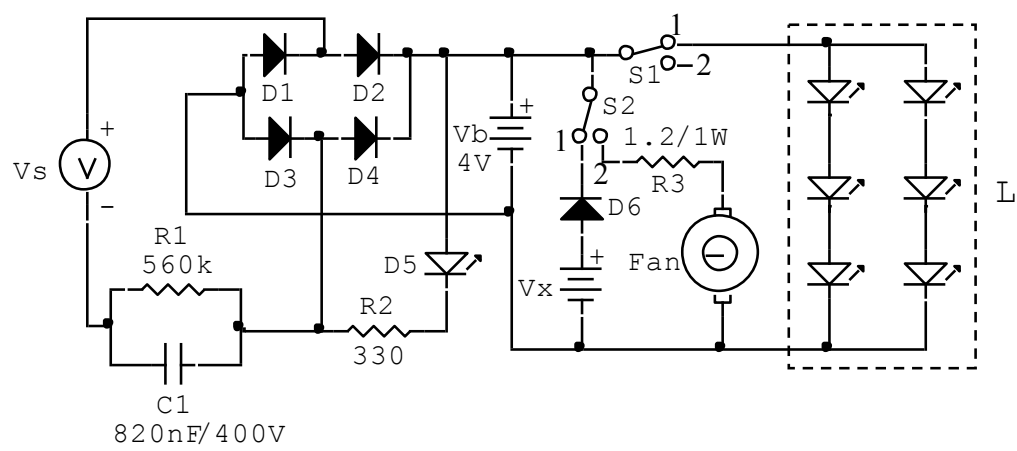

Gambar 7. Diagram rangkaian Lampu-C

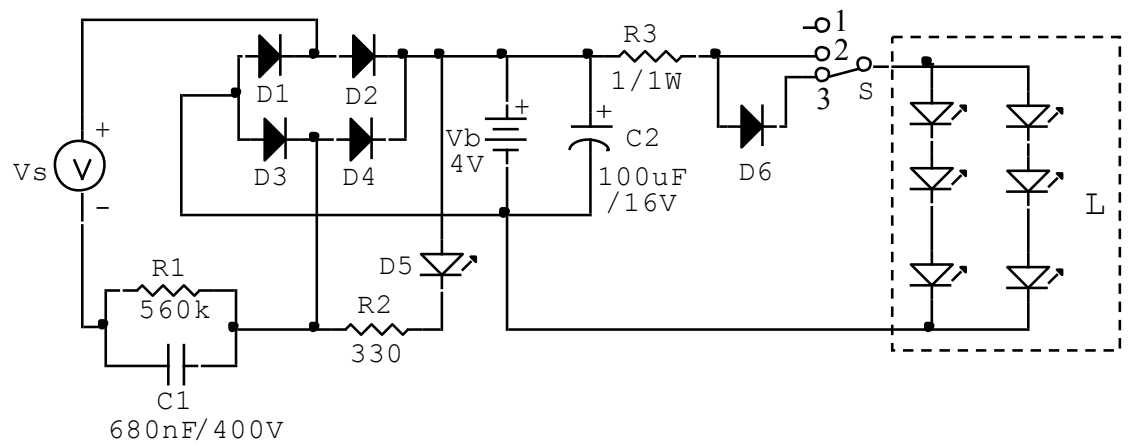

Gambar 8. Diagram rangkaian Lampu-D

Simbol L, L2 dalam masing masing produk tersebut adalah berupa deretan lampu LED (seri-paralel) yang merupakan lampu utama. Pada Lampu- $A$ dan - $D$ terdapat saklar untuk memilih apakah lampu dimatikan (posisi 1), dinyalakan terang (posisi 2) atau redup (posisi 3). Pada Lampu-B, saklar digunakan untuk mematikan lampu (posisi 1), menyalakan lampu utama (posisi 2) dan menghidupkan lampu LED L1 sebagai lampu senter (posisi 3). Pada Lampu-C terdapat satu kipas angin kecil yang diaktifkan jika saklar $S_{2}$ berada di posisi 2. Terdapat pula tempat untuk baterai eksternal (Vx). Jika menggunakan catu $V \times$ maka hanya lampu L yang bisa dihidupkan dengan mengatur $\mathrm{S}_{1}$ dan $S_{2}$, keduanya ke posisi 1.

Tabel 1 menunjukkan intensitas cahaya rerata untuk masing-masing produk ketika lampu utama dihidupkan. Untuk Lampu- $A$ dan $-D$, saklar dipilih pada posisi lampu terang maksimal. Pengukuran dilakukan dengan menggunakan lux-meter yang menghadap ke arah lampu yang dinyalakan dengan jarak $17 \mathrm{~cm}$, yang sama dengan jarak antara lampu dengan permukaan meja ketika digunakan. Pengukuran dilakukan di malam hari dengan mematikan sumber cahaya sekitar.

\begin{tabular}{cc} 
Tabel & \multicolumn{3}{c}{ Intensitas cahaya masing-masing jenis lampu baca } \\
\cline { 2 - 3 } Jenis Lampu & Intensitas (lux) \\
\hline A & 700 \\
B & 630 \\
C & 1200 \\
D & 710 \\
\hline
\end{tabular}


Nilai-nilai intensitas tersebut telah melampaui standar pencahayaan untuk membaca yaitu 300-500 lux [11]. Intensitas cahaya dapat diatur dengan menjauhkan atau mendekatkan lampu dengan permukaan meja melalui lengan penyangga lampu fleksibel yang terdapat pada keempat jenis lampu tersebut.

\subsection{Analisis, Simulasi dan Pengukuran Rangkaian Charger Baterai}

Karena penelitian ini difokuskan pada charger baterai yang ada di tiap produk lampu, maka rangkaian diuji tanpa melibatkan beban lain, sehingga lampu utama, lampu senter dan kipas dimatikan selama pengukuran.

Dengan memperhatikan Gambar 5 sampai Gambar 8 dapat disimpulkan bahwa semua lampu menggunakan charger yang sederhana, tanpa adanya sensor untuk umpanbalik pengendalian pengisian baterai. Pada prinsipnya rangkaian charger yang digunakan ditunjukkan pada Gambar 9.

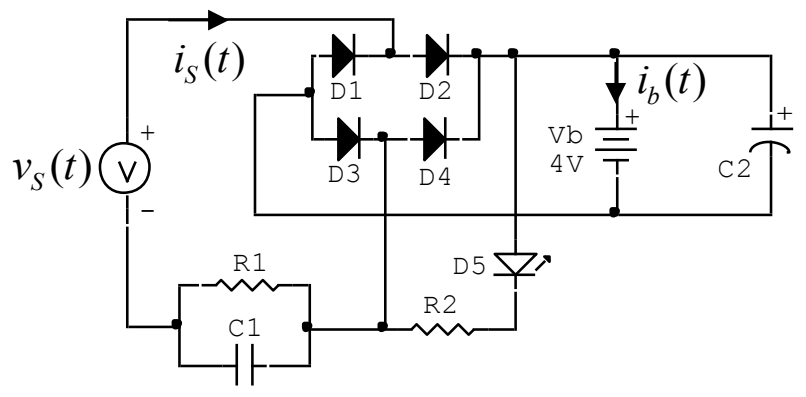

Gambar 9. Rangkaian dasar charger yang digunakan

Mengacu ke Gambar 9, komponen atau parameter yang sama yang digunakan pada keempat jenis produk lampu adalah: Dioda $D_{1}-D_{4}$ menggunakan tipe 1 N4007, LED $\left(D_{5}\right)$ yang berfungsi sebagai indikator pengisian baterai merupakan LED warna merah berukuran $5 \mathrm{~mm}$. Tegangan nominal baterai SLA yang dipakai $\left(V_{\mathrm{b}}\right)$ adalah $4 \mathrm{~V}$. Namun ada sejumlah variasi pada masing-masing produk yang ditunjukkan pada Tabel 2.

Tabel 2 Variasi komponen atau parameter masing-masing produk lampu

\begin{tabular}{cccccccc}
\hline Jenis Lampu & $C_{1}(\mu \mathrm{F})$ & $V_{\mathrm{C} 1 \mathrm{M}}(\mathrm{V})$ & $R_{1}(\mathrm{k} \Omega)$ & $C_{2}(\mu \mathrm{F})$ & $V_{\mathrm{C} 2 \mathrm{M}}(\mathrm{V})$ & $R_{2}(\Omega)$ & $C_{\text {bat }}(\mathrm{mAh})$ \\
\hline A & 1 & 250 & 390 & 100 & 50 & 1000 & 1000 \\
B & 0,82 & 400 & 330 & 220 & 35 & 330 & 800 \\
C & 0,82 & 400 & 560 & - & - & 330 & 600 \\
D & 0,68 & 400 & 560 & 100 & 16 & 330 & 1000 \\
\hline
\end{tabular}

Catatan: $V_{\mathrm{C} 1 \mathrm{M}}\left(V_{\mathrm{C} 2 \mathrm{M}}\right)$ adalah tegangan nominal kapasitor $C_{1}\left(C_{2}\right)$

\section{Metode Pengisian Baterai yang Digunakan}

Pada Gambar 9, sumber tegangan vs berasal dari jala-jala listrik PLN maka:

$$
v_{S}(t)=V_{M} \sin (\omega t)=314 \sin (100 \pi t) \mathrm{V}
$$

Diode $D_{1}-D_{4}$ membentuk konfigurasi penyearah gelombang penuh. Setiap kali terjadi pengisian, arus is $(t)$ melewati dua buah diode dan baterai $V_{\mathrm{b}}$, sehingga tegangan jatuhnya $2 \times 0,7 \mathrm{~V}+V_{\mathrm{b}}=5,4 \mathrm{~V}$. Karena $V_{\mathrm{M}}>>5,4 \mathrm{~V}$, maka untuk menghitung is $(t)$ tegangan jatuh tersebut bisa diabaikan sehingga diperoleh:

$$
i_{S}(t)=I_{M} \sin (100 \pi t+\theta)
$$


dengan:

$$
I_{M}=\frac{V_{M} \sqrt{1+\left(100 \pi R_{1} C_{1}\right)^{2}}}{R_{1}}
$$

$$
\theta=\tan ^{-1}\left(100 \pi R_{1} C_{1}\right)
$$

Hasil perhitungan $I_{\mathrm{rms}}=I_{\mathrm{M}} / \sqrt{2}$, dengan $I_{\mathrm{M}}$ sesuai Persamaan (3), untuk masing-masing lampu ditunjukkan pada Tabel 3. Nilai tegangan jala-jala diasumsikan konstan, $V_{\mathrm{M}}=314 \mathrm{~V}$ atau $V_{\mathrm{RMS}}=220 \mathrm{~V}$. Hasil perhitungan IRMs juga dibandingkan dengan hasil pengukuran menggunakan sebuah true-RMS multimeter. Arus sumber tersebut sebagian digunakan untuk mengisi baterai. Indikator pengisian berupa sebuah LED $5 \mathrm{~mm}$ diseri dengan $R_{2}$, dipasang seperti pada Gambar 9 agar LED hanya menyala ketika terdapat tegangan jalajala, dan tidak menarik arus dari baterai $V_{\mathrm{b}}$.

Tabel 3. Hasil perhitungan dan pengukuran IRMS

\begin{tabular}{cccc}
\hline Jenis Lampu & $I_{\text {RMS(perhitungan) }}(\mathrm{mA})$ & $I_{\text {RMS(pengukuran) }(\mathrm{mA})}$ & Selisih $(\%)$ \\
\hline A & 70 & 72 & 3 \\
B & 57 & 56 & 2 \\
C & 57 & 56 & 2 \\
D & 48 & 47 & 2 \\
\hline
\end{tabular}

Dengan adanya penyearah gelombang penuh $D_{1}-D_{4}$ maka saat pengisian berlangsung, arus pada baterai selalu positif (masuk melalui kutub positif baterai) dan berbentuk seperti keluaran penyearah gelombang penuh sinusoida. Karena arus sumber diasumsikan sinusoidal maka faktor bentuknya (form factor), yaitu perbandingan nilai RMS dan nilai reratanya adalah 1,1. Tabel 4 menunjukkan perhitungan nilai DC dari arus sumber $(\mathrm{IDC})$ dibandingkan dengan hasil pengukuran nilai DC arus pengisian baterai (IbDC).

\begin{tabular}{l} 
Tabel 4. Hasil perhitungan IDC dan hasil pengukuran $I_{\mathrm{bDC}}$ \\
\cline { 2 - 3 } \\
\begin{tabular}{cccc} 
Jenis Lampu & $I_{\mathrm{DC}}(\mathrm{mA})$ & $I_{\mathrm{bDC}}(\mathrm{mA})$ \\
\hline A & 63,6 & 58 \\
$\mathrm{~B}$ & 51,8 & 44 \\
C & 51,8 & 43 \\
D & 43,6 & 36 \\
\hline
\end{tabular}
\end{tabular}

Dari Tabel 4 terlihat bahwa $I_{\mathrm{DC}}>\mathrm{I}_{\mathrm{bDC}}$, hal ini dikarenakan ada sebagian arus sumber yang mengalir ke LED, dan ke kapasitor $C_{2}$. Dengan arus pengisian IbDC maka dapat diperkirakan durasi pengisian baterai dari kosong sampai penuh, $T=C_{\text {bat }} / I_{b D C}$, untuk

\begin{tabular}{|c|c|c|}
\hline Jenis Lampu & $C_{\text {bat }}(\mathrm{Ah})$ & $T(\mathrm{~h})$ \\
\hline $\mathrm{A}$ & 1 & 17 \\
\hline B & 0,8 & 18 \\
\hline C & 0,6 & 14 \\
\hline D & 1 & 28 \\
\hline
\end{tabular}
masing-masing produk lampu seperti ditunjukkan Tabel 5.

Setelah penuh, baterai akan tetap diisi dengan arus rerata sebesar IbDc.

Kapasitor $C_{2}$ yang ada pada Lampu- $A,-B,-D$, berfungsi untuk meratakan arus pengisian baterai. Tabel 6 menunjukkan perbandingan nilai DC arus pengisian baterai 
( $\mathrm{bDC})$ dengan nilai AC arus pengisian baterai ( $\mathrm{b}_{\mathrm{bAC}}$ ). Nilai $\mathrm{IbAC}_{\mathrm{b}}$ adalah nilai efektif dari riak arus pengisian baterai.

\begin{tabular}{ccccc}
\multicolumn{5}{c}{ Tabel 6. Perbandingan nilai DC dan AC arus pengisian baterai } \\
\hline Jenis Lampu & IbDC $(\mathrm{mA})$ & IbAC $(\mathrm{mA})$ & IbAC/IbC $(\%)$ & Cbat/ 20 \\
\hline A & 58 & 34 & 58 & 50 \\
B & 44 & 21 & 48 & 40 \\
C & 43 & 31 & 73 & 30 \\
D & 36 & 24 & 66 & 50 \\
\hline
\end{tabular}

Tabel 6 menunjukkan Lampu-C yang tidak menggunakan kapasitor $C_{2}$ memiliki rasio $I_{b A C}$ terhadap $I_{b D C}$ terbesar, yang mengindikasikan amplitude riak arusnya relatif paling besar. Sedangkan Lampu- $B$ yang memiliki $C_{2}$ terbesar, rasionya paling kecil yang menunjukkan arus pengisian baterai relatif paling rata.

\section{Potensi Kerusakan Komponen Akibat Metode Pengisian yang Digunakan}

Berdasarkan hasil pengujian selama tiga bulan, dengan menghubungkan lampu ke jala-jala listrik PLN, yang berarti baterai terus menerus diisi, terdapat empat buah lampu (dari 12 yang diuji) yang baterainya rusak. Tiga di antaranya merupakan baterai pada Lampu- $C$, dan yang satu merupakan baterai Lampu- $A$. Jenis kerusakannya adalah baterai tidak bisa diisi lagi atau bersifat hubung buka.

Analisis penyebab kerusakan tersebut adalah sebagai berikut. Dari Tabel 4 dan Tabel 5 didapatkan rasio $\mathrm{IbDC} / C_{\text {bat }}$ yang sama dengan $1 / T$, berada dalam rentang $1 / 28$ (baterai pada Lampu-D) sampai $1 / 14$ (baterai pada Lampu-C). Nilai tersebut terlalu besar karena untuk float charging, rasio tersebut seharusnya sekitar 1/500 [2]. Khususnya untuk Lampu- $C$, rerata arus pengisian bernilai 500/14 atau 36 kali lipat lebih besar dari yang disarankan.

Terlebih lagi arus pengisian baterai bukan arus konstan melainkan berbentuk gelombang sinus yang disearahkan, sehingga memiliki riak (ripple) yang besar, yang memperpendek umur baterai. Berdasarkan [12], nilai riak arus pengisian maksimum yang disarankan pabrikan baterai adalah $C_{\text {bat }} / 20$. Dari Tabel 6 terlihat bahwa Lampu-C memiliki nilai riak arus pengisian yang melebihi nilai rekomendasi tersebut, atau $\mathrm{IbAC}_{\mathrm{b}}>\mathrm{C}_{\text {bat }} / 20$.

Pada Lampu- $A$ yang baterainya rusak tersebut, terdapat pula komponen lain yang ikut rusak yaitu kapasitor perata arus $\left(C_{2}\right)$, serta komponen indikator pengisian baterai yaitu $R_{2}$. Analisis berikut ini menunjukkan bahwa kerusakan baterai, dalam hal ini tidak lagi bisa diisi atau bersifat hubung buka, dapat menimbulkan dampak susulan yaitu rusaknya kedua komponen tersebut.

Rangkaian Lampu- $A$ yang baterainya rusak baterai (hubung buka) ditunjukkan pada Gambar 10. 


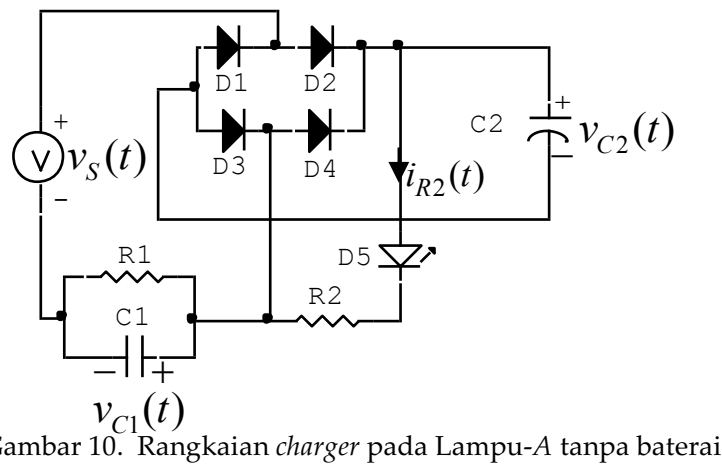

Untuk mempermudah analisis, $R_{2}$ dan $D_{5}$ dilepas dulu, maka rangkaian akan berfungsi sebagai detektor tegangan puncak, dan tegangan kapasitor $C_{2}, v_{c_{2}}(t)$ akan diisi sehingga mencapai $V_{\mathrm{M}}$. Kapasitor $C_{2}$ diisi jika dipenuhi $v_{\mathrm{s}}(t)>v_{\mathrm{C}_{1}}(t)+v_{\mathrm{C}_{2}}(t)$, atau $v_{\mathrm{C}_{1}}(t)-$ $v_{\mathrm{s}}(t)>v_{\mathrm{C}_{2}}(t)$. Nilai $v_{\mathrm{C}_{2}}(t)$ akan naik seiring waktu, sedangkan $v_{\mathrm{c}_{1}(t)}$ akan turun sampai akhirnya menuju nol ketika $v_{\mathrm{C} 2}=V_{\mathrm{M}}=314 \mathrm{~V}$. Hal ini ditunjukkan oleh hasil simulasi rangkaian Gambar 11 untuk Lampu- $A$, menggunakan perangkat lunak Circuit Maker.

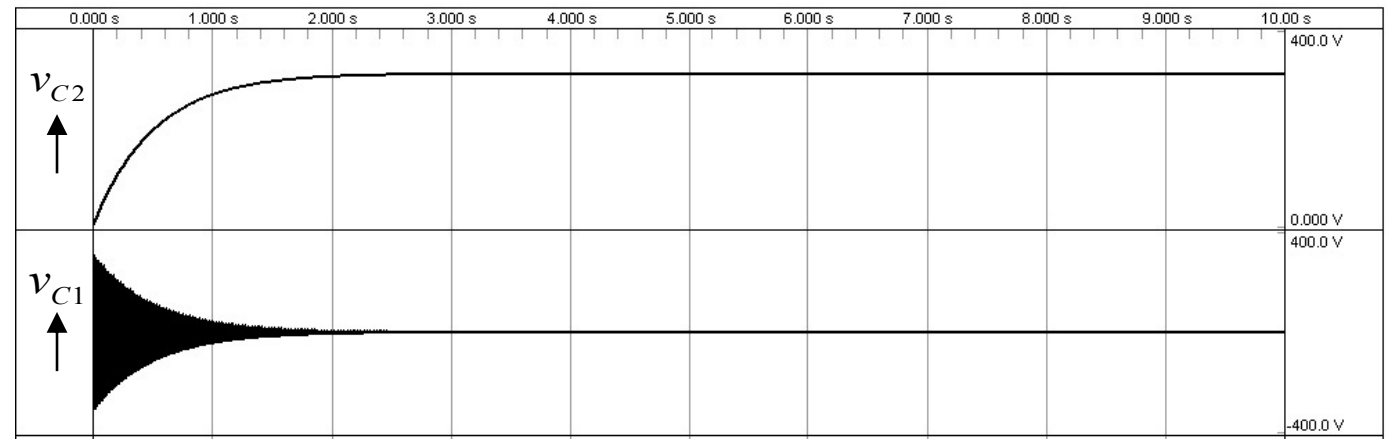

Gambar 11. Hasil simulasi bentuk gelombang $v \mathrm{c}_{1}(t)$ dan $v_{\mathrm{c} 2}(t)$ pada Lampu- $A$ tanpa adanya $R_{2}$ dan $D_{5}$

Jika $R_{2}$ dan $D_{5}$ dipasang maka terdapat jalur pengisian dari sumber tegangan ke $C_{1}$ sehingga tegangan $C_{1}$ dapat mencapai $V_{\mathrm{M}}$, maka tegangan pada $C_{2}$ akan dapat mencapai $2 V_{\mathrm{M}}$, sehingga rangkaian bersifat seperti pengganda tegangan (voltage doubler). Seperti ditunjukkan pada Gambar 12, tegangan $C_{2}$ menurut hasil simulasi mencapai $2 V_{\mathrm{M}}=628 \mathrm{~V}$.

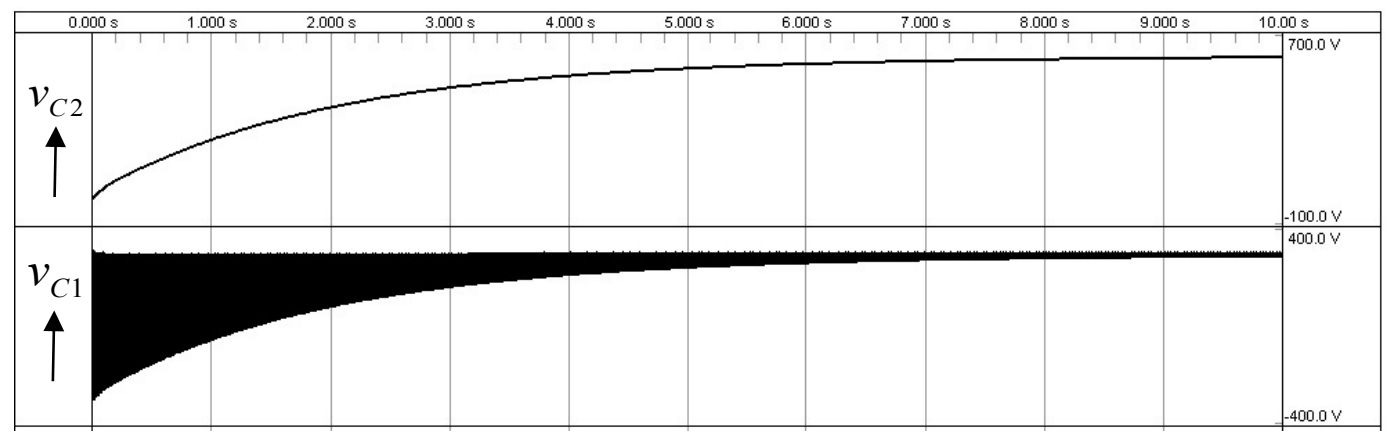

Gambar 12. Hasil simulasi bentuk gelombang $v_{C 1}(t)$ dan $v_{C 2}(t)$ pada Lampu- $A$ dengan adanya $R_{2}$ dan $D_{5}$

Hasil yang sama juga didapat untuk rangkaian Lampu- $B$ dan $-D$, padahal tegangan nominal atau rating tegangannya $\left(V_{\mathrm{C} 2 \mathrm{M}}\right)$ yang tertera di badan kapasitor $C_{2}$ untuk Lampu- 
$A,-B,-D$ hanya berkisar antara $16 \mathrm{~V}$ sampai $50 \mathrm{~V}$. Dengan demikian jika baterai rusak, tidak bisa diisi sehingga bersifat hubung buka, maka $C_{2}$ mendapat tegangan yang sangat besar. Untuk memverifikasi hasil simulasi tersebut, dilakukan pengukuran tegangan $C_{2}$ pada Lampu- $A,-B$ dan $-D$, dengan kondisi baterai dilepas, hasilnya ditunjukkan pada Tabel 7. Tegangan yang terukur tersebut diperoleh sebelum semua kapasitor tersebut rusak akibat nilai tegangannya jauh melampaui nilai tegangan nominal atau rating-nya.

Tabel 7. Hasil pengukuran tegangan $C_{2}$ pada saat baterai rusak (tidak bisa diisi)

\begin{tabular}{cc}
\hline Jenis Lampu & $v \mathrm{c} 2(\mathrm{~V})$ \\
\hline $\mathrm{A}$ & 95 \\
$\mathrm{~B}$ & 62 \\
$\mathrm{D}$ & 75 \\
\hline
\end{tabular}

Berdasarkan Tabel 7, tegangan kapasitor hasil pengukuran tidak pernah mencapai nilai seperti Gambar 11 dan Gambar 12 karena kapasitor mengalami kedadalan dielektrik sehingga tegangannya tidak bisa naik lagi meskipun terus diberi arus, dan setelah beberapa waktu kapasitor menjadi rusak.

Pada saat-saat awal kapasitor $C_{2}$ diisi (masih kondisi transien) dan tegangannya menuju 2V $\mathrm{V}_{\mathrm{M}}$ seperti Gambar 12, maka LED $D_{5}$ akan mendapat arus setiap setengah periode $v$ s, yaitu saat $v s(t)>v_{1}(t)+v_{C_{2}}(t)$. Nilai arus pada $R_{2}$, atau $i_{R_{2}}(t)$, mendekati nilai arus sumber namun hanya untuk setengah periode $(10 \mathrm{~ms})$, seperti ditunjukkan oleh hasil simulasi Gambar 13 untuk Lampu- $A$.

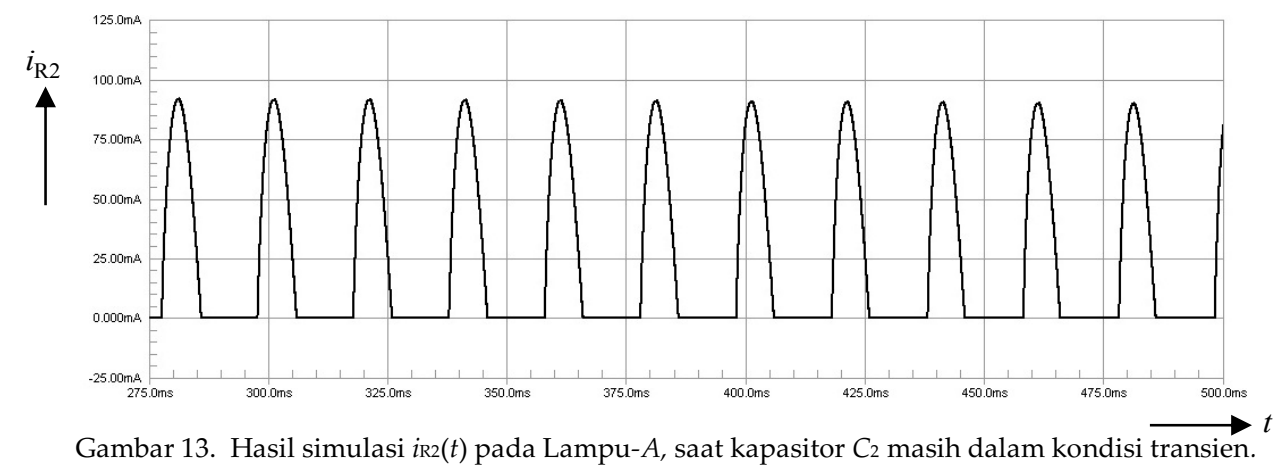

Nilai DC atau rerata arus $i_{\mathrm{R} 2}(t)$ adalah:

$$
I_{R 2 D C}=\frac{1}{20 m} \int_{0}^{10 m} I_{M} \sin (100 \pi t) d t=\frac{I_{\mathrm{M}}}{\pi}
$$

Nilai IM dihitung menggunakan Persamaan (3). Hasil perhitungan $I_{R 2 D C}$ dan hasil pengukurannya pada kondisi transien $C_{2}$, untuk Lampu- $A,-B,-D$ ditunjukkan pada Tabel 8. Lampu- $C$ tidak diperhitungkan karena tidak memiliki kapasitor $C_{2}$.

Tabel 8. Hasil perhitungan dan pengukuran $I_{\text {R2DC }}$ saat kapasitor $C_{2}$ dalam kondisi transien

\begin{tabular}{cccc}
\hline $\begin{array}{c}\text { Jenis } \\
\text { Lampu }\end{array}$ & $\begin{array}{c}I_{\text {R2DC(perhitungan) }} \\
(\mathrm{mA})\end{array}$ & $\begin{array}{c}I_{\mathrm{R} 2 \mathrm{DC}(\text { pengukuran) }} \\
(\mathrm{mA})\end{array}$ & $\begin{array}{c}\text { Selisih } \\
(\%)\end{array}$ \\
\hline $\mathrm{A}$ & 22 & 21 & 4,5 \\
$\mathrm{~B}$ & 26 & 22 & 15 \\
$\mathrm{D}$ & 21 & 18 & 14 \\
\hline
\end{tabular}

Daya rerata pada $R_{2}$ adalah:

Daya puncak pada $R_{2}$ adalah:

$$
P_{R 2 a v g}=I_{R 2 D C}^{2} R_{2}=\frac{I_{M}^{2}}{\pi^{2}} R_{2}
$$

$$
P_{R 2 \text { peak }}=I_{M}^{2} R_{2}
$$


Hasil perhitungan menggunakan Persamaan 6 dan 7 pada saat $C_{2}$ dalam kondisi transien ditunjukkan pada Tabel 9.

\begin{tabular}{ccc} 
Tabel 9. Hasil perhitungan daya rerata dan daya puncak pada & $R_{2}$ \\
\hline Jenis Lampu & $P_{\mathrm{R} 2 a v g}(\mathrm{~W})$ & $P_{\mathrm{R} 2 \text { peak }}(\mathrm{W})$ \\
\hline A & 0,49 & 9,8 \\
B & 0,22 & 2,2 \\
D & 0,14 & 1,5
\end{tabular}

Rating daya resistor $R_{2}$ yang digunakan untuk keempat lampu tersebut adalah 0,25W, jadi hanya Lampu- $A$ yang daya reratanya berlebihan. Namun demikian karena semua resistor mendapat daya puncak yang tinggi, melebihi rating dayanya, maka resistor menjadi panas dan ada yang rusak terbakar, yaitu pada Lampu- $A$.

Rangkaian charger pada Lampu- $C$, yang tidak memiliki $C_{2}$, tidak mengalami masalah jika baterai rusak (tidak bisa diisi). Karena rangkaian Gambar 10 jika tanpa $C_{2}$ akan bersifat seperti detektor tegangan puncak, dalam hal ini tegangan $C_{1}$ akan terisi melalui $R_{2}$, sampai tegangannya mencapai $V_{\mathrm{M}}$ lalu pengisian berhenti, sehingga arus $R_{2}$ nol. Kapasitor $C_{1}$ akan mengosongkan tegangan melalui $R_{1}$ secara lambat (tetapan waktu, $\tau=R_{1} C_{1}=270 \mathrm{~ms}$ ), dan ketika nilai $v$ s mencapai $V_{\mathrm{M}}$ maka $C_{1}$ akan diisi lagi, sehingga $R_{2}$ dialiri arus namun hanya sesaat karena $v_{\mathrm{C} 1}$ segera menjadi $V_{\mathrm{M}}$ lagi, begitu seterusnya, seperti ditunjukkan Gambar 14.

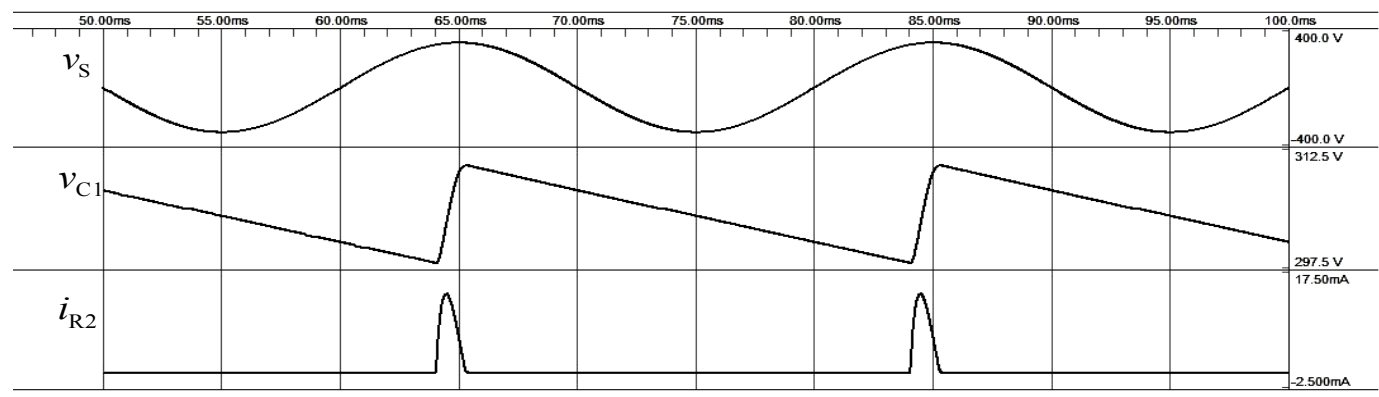

Gambar 14. Hasil simulasi bentuk gelombang arus $i_{\mathrm{R} 2}(t)$ pada Lampu- $C$, saat baterai rusak (hubung buka).

Terlihat pada Gambar 14, $R_{2}$ akan dialiri pulsa-pulsa arus dengan amplitude kecil yang tidak merusakkannya karena daya puncak yang dirasakan jauh dibawah rating dayanya. Rerata $i_{\mathrm{R} 2}$ sekitar $0,55 \mathrm{~mA}$, sangat mendekati hasil pengukuran yaitu $0,5 \mathrm{~mA}$, atau daya puncaknya $82 \mu \mathrm{W}$, jauh di bawah rating dayanya yaitu $250 \mathrm{~mW}$. Dengan arus tersebut, LED indikator pengisian baterai yang terdapat pada rangkaian masih dapat menyala cukup terang dengan aman.

\section{Kesimpulan}

Beberapa kesimpulan yang bisa diambil setelah dilakukan penelitian ini adalah sebagai berikut ini.

1. Semua produk lampu yang diteliti menggunakan rangkaian pengisi baterai sederhana tanpa sensor pendeteksi baterai penuh. Rasio rerata arus pengisian baterai $\left(\mathrm{IbDC}_{\mathrm{bD}}\right)$ terhadap kapasitas baterai ( $C_{\text {bat }}$ ) untuk keempat jenis produk berada dalam rentang 1/28 (Lampu-D) sampai 1/14 (Lampu-C). Nilai tersebut jauh di atas yang disarankan untuk pengisian baterai SLA secara terus menerus (float charging) yaitu 1/500, sehingga menimbulkan overcharging. 
2. Arus pengisian memiliki riak yang besar, antara $48 \%$ sampai $73 \%$ dari nilai reratanya. Pada Lampu- $C$, yang tidak menggunakan kapasitor perata, nilai efektif riak arus pengisiannya melampaui batas yang disarankan pabrikan yaitu $C_{\text {bat }} / 20$.

3. Pengisian baterai selama tiga bulan secara float charging menyebabkan satu Lampu- $A$ rusak dan tiga Lampu- $C$ rusak, sebagai akibat dari arus yang berlebih dan riak arus pengisian yang terlalu besar seperti disebutkan pada poin 1 dan 2 .

4. Kerusakan baterai yang diamati adalah baterai tidak lagi bisa diisi arus atau bersifat hubung buka. Pengujian menunjukkan hal tersebut menyebabkan tegangan kapasitor perata arus $\left(C_{2}\right)$ pada Lampu- $A,-B$ dan $-D$ mencapai nilai antara $75 \mathrm{~V}$ sampai $95 \mathrm{~V}$, jauh di atas nilai tegangan nominal kapasitor yang dipakai (16V sampai 50V) sehingga pada akhirnya kapasitor rusak.

5. Kerusakan baterai juga akan membuat resistor pembatas arus indikator LED $\left(R_{2}\right)$ mendapatkan arus puncak yang besar saat $C_{2}$ dalam kondisi transien, sehingga resistor tersebut ada yang mengalami kerusakan (Lampu- $A$ ) karena daya reratanya $(0,49 \mathrm{~W})$ dan daya puncaknya $(9,8 \mathrm{~W})$ melampaui rating dayanya $(0,25 \mathrm{~W})$.

6. Pada Lampu-C yang tidak memiliki $C_{2}$, ketika baterai rusak, arus $R_{2}$ berupa pulsa beramplitudo kecil dengan rerata sekitar $0,5 \mathrm{~mA}$ sehingga LED 5mm yang dipakai tetap dapat menyala dengan aman.

\section{Daftar Pustaka}

[1] D. Rohi, J. E. Luik, Kesadaran Masyarakat Surabaya untuk Memiliki Gaya Hidup Ramah Lingkungan "Green Living" Melalui Menghemat Penggunaan Energi Listrik [Online],

http://repository.petra.ac.id/16377/1/Publikasi1_97030_905.pdf, diakses tanggal 20 Maret 2019.

[2] D. Linden, TP Reddy, Handbook of Batteries, McGraw-Hill, New York, 2002, $33^{\text {rd }}$ ed.

[3] C. M. Dinis et. al, 2015, "Study on Sources of Charging Lead Acid Batteries", Conf. Ser.: Mater. Sci. Eng. 8501201.

[4] Y. S Wong et al., "Charge Regimes for Valve-regulated Lead-Acid Batteries: Performance Overview Inclusive of Temperature Compensation", Journal of Power Sources, vol. 183, no. 2, pp. 783-791, September 2008.

[5] J. Jana et al., "Design and Development of High Efficiency Five Stage Battery Charge Controller with Improved MPPT Performance for Solar PV Systems", International Journal of Renewable Energy Research, vol. 8, no. 2, June 2008.

[6] S. Ying, A. F. Christopher, R. Chris., "Capacity Recovery of a Sulfated Lead-Acid Battery Using Pressure Feedback Charging Control", in. Proc. ASME 2012 5th Annual Dynamic Systems and Control Conference joint with the JSME 2012 11th Motion and Vibration Conference, Fort Lauderdale, Florida, USA, 17-19 October 2012.

[7] A. Singh, P. B. Karandikar, "Review on Desulfation of Lead-Acid Battery for HEV", International Journal of Current Engineering And Scientific Research, vol. 2, no. 9, 2015.

[8] Y Yin et al., "A Battery Charging Control Strategy for Renewable Energy Generation Systems", Proceedings of the World Congress on Engineering 2008, vol. 1, London, U.K., July 2- 42008. 
[9] Yee Wan Wong et al., "A New State-of-Charge Estimation Method for Valve Regulated Lead-Acid Batteries", Journal of Engineering Science and Technology, vol. 12, no. 3 pp. 584-595, 2017.

[10]H. Eduardo Ariza Chacón et al., "Modelling, Parameter Identification, and Experimental Validation of a Lead Acid Battery Bank Using Evolutionary Algorithms", Energies, vol. 11, no. 9, September 2018.

[11]Narein Perera, Nirma Swaris, "Good Reading Light: Visual Comfort Perception and Daylight Integration in Library Spaces", Proceedings of the $10^{\text {th }}$ International Conference of Faculty of Architecture Research Unit (FARU), At University of Moratuwa, Sri Lanka, 8-10 December, 2017.

[12]Emerson-Network Power, Effects of AC Ripple Current on VRLA Battery Life [Online], http://www.aeroelectric.com/Reference_Docs/Battery/Effects $200 f$ $\div 20 \mathrm{AC} \div 20 \mathrm{Ripple} \div 20 \mathrm{Current} \div 200 n \div 20 \mathrm{VRLA} \div 20 \mathrm{Battery} \div 20 \mathrm{Life} . \mathrm{pdf}$, diakses tanggal 20 Maret 2019. 
